\title{
POSSIBILITIES OF ELIMINATING THE HIGHER AMOUNT OF IR0N IN SECONDARY AISi7Mg0.3 ALLOY BY CHROME
}

\begin{abstract}
This paper deals with influence on segregation of iron based phases by chrome. Iron is one of the most common impurities that could be found in Al-Si alloys. It is impossible to remove iron from melt by standard operations, but it is possible to eliminate its negative influence by addition of some other elements that affect the segregation of intermetallics in less harmful type. Realization of experiments and results of analysis show new perspective on solubility of iron based phases during melt preparation with higher iron content and influence of chrome as iron corrector of iron based phases. It could be concluded that higher amount of chrome causes the formation of sludge particles.
\end{abstract}

Keywords: Secondary AlSi7Mg0.3 based alloys, iron phases, thermal analysis, iron correctors, AlCr20.

\section{Introduction}

Due to increasing requirements on the quality of castings, final fatigue properties and due to the pressure on price of final castings, it is necessary to search compromises in the casting production from secondary alloys with the presence of various impurities. A basis for initiating this work was lack of theoretical knowledge of using secondary Al-Si-Mg alloys with higher amount of iron and its appropriate and efficient elimination in production of demanding casting for automotive industry by serial conditions [1 - 3].

The increased content of iron in aluminium alloy has a consequent exclusion of intermetallic phases in various forms which affect the final quality and durability of castings. The adverse effect of iron on the final properties of the casting is that it greatly affects the mechanical properties [4 and 5].

Iron cannot be removed from melt by conventional procedures, but it is possible to eliminate the adverse effect by adding some elements which affect the exclusion of iron intermetallic phases in the less adverse form. The input to solve this problem was detection that in the literature are a number of elements (e.g. Mn, $\mathrm{Cr}, \mathrm{Ni}, \mathrm{V}, \mathrm{Zr}, \mathrm{Co}$ ) which affect the exclusion of iron based phases, but their using in practice is neither widespread nor implemented [6].

Chrome occurs as impurity in commercially available master alloy, in the range from 5 to $50 \mu \mathrm{m}$, provides strength at room temperature and slightly increases the ductility. The presence of $\mathrm{Cr}$ phases $\mathrm{Al}_{13} \mathrm{Si}_{4}(\mathrm{CrFe})_{4}$ and $\mathrm{Al}_{2} \mathrm{Si}_{8}(\mathrm{CrFe})_{5}$ can increase brittleness [7 - 9].
Using chrome, a similar effect on the exclusion of phases was observed as with manganese, but without a clearer microstructural explanation. The presence of chromium, together with iron and manganese can cause the exclusion of so-called "sludge" particles [10].

\section{Experimental work}

\subsection{Experimental notes}

Experimental melts were executed at the Department of Technological Engineering, University of Zilina. Metal was melted in an electrical resistance furnace T15, controlled by PID regulator CAL 3200 in a graphite crucible treated by protective coating. Individual casts consisted of creating four samples poured at a temperature $760 \pm 5{ }^{\circ} \mathrm{C}$. Melt was not refined and was without addition of a modifier or grain refiner. The only operations during melt preparation were stirring and oxide film removal from the melt surface. Melt was poured into a metal mold with minimal temperature of $100{ }^{\circ} \mathrm{C}$.

$\mathrm{A} 1 \mathrm{Si} 7 \mathrm{Mg} 0.3$ cast alloy was used as an experimental material. The chemical composition of the used alloy is shown in Table 1. This alloy finds applications in automotive, aerospace and general engineering industries due to its excellent combination of properties such as good fluidity, low coefficient of thermal expansion, high strength-to-weight ratio and good corrosion resistance. This foundry alloys have excellent tensile and fatigue properties and also good corrosion resistance.

\footnotetext{
* 'Dana Bolibruchova, ${ }^{1}$ Lukas Richtarech, ${ }^{2}$ Wladyslaw Orlowicz

${ }^{1}$ Department of Technological Engineering, Faculty of Mechanical Engineering, University of Zilina, Slovakia

${ }^{2}$ Rzeszow University of Technology, Faculty of Mechanical Engineering and Aeronautics, Rzeszow, Poland

Email: lukas.richtarech@fstroj.uniza.sk
} 


\section{COMMNICOIIONS}

Chemical composition of AlSi7Mg0.3 cast alloy

Table 1

\begin{tabular}{|c|c|c|c|c|c|c|c|c|c|c|c|}
\hline Elements & $\mathrm{Si}$ & $\mathrm{Fe}$ & $\mathrm{Cu}$ & $\mathrm{Mn}$ & $\mathrm{Mg}$ & $\mathrm{Ni}$ & $\mathrm{Cr}$ & $\mathrm{Pb}$ & $\mathrm{Ti}$ & $\mathrm{Zn}$ & $\mathrm{Sb}$ \\
\hline [wt. \%] & 6.93 & 0.1204 & 0.0036 & 0.0037 & 0.3896 & 0.0042 & 0.0011 & 0.0033 & 0.1141 & 0.0083 & 0.0001 \\
\hline
\end{tabular}

Chemical composition of $\mathrm{AlSi} 7 \mathrm{Mg} 0,3$ cast alloy after addition of iron

Table 2

\begin{tabular}{|c|c|c|c|c|c|c|c|c|c|c|c|}
\hline Elements & $\mathrm{Si}$ & $\mathrm{Fe}$ & $\mathrm{Cu}$ & $\mathrm{Mn}$ & $\mathrm{Mg}$ & $\mathrm{Ni}$ & $\mathrm{Cr}$ & $\mathrm{Pb}$ & $\mathrm{Ti}$ & $\mathrm{Zn}$ & $\mathrm{Sb}$ \\
\hline [wt. \%] & 6.49 & 1.280 & 0.053 & 0.092 & 0.349 & 0.034 & 0.087 & 0.006 & 0.113 & 0.027 & $<0.0004$ \\
\hline
\end{tabular}

Certain amount of AlFe10 master alloy (deliberate "contamination") was added to experimental alloy to increase the iron content. The main aim was to increase the iron content in alloy so that the amount would be close to the maximal allowed content by customer specification for automotive components made from secondary alloys $\mathrm{AlSi} 7 \mathrm{Mg} 0.3$. The amount of AlFe10 added to the basic AlSi7Mg0.3 was 70000 ppm of the total batch. The chemical composition of alloy with a higher amount of iron is shown in Table 2.

Influence of the iron amount on the microstructure and shape of intermetallic phases was studied by the classic black - white contrast method. Sample preparation and execution of metallographic image was done in a standard way for the evaluation of intermetallic phases in aluminum alloys. Evaluated samples were etched by $20 \mathrm{ml}$ of $\mathrm{H}_{2} \mathrm{SO}_{4}+100 \mathrm{ml}$ of $\mathrm{H}_{2} \mathrm{O}$. Images of alloy microstructures were obtained by the light microscope NEOPHOT 32. In Fig. 1 is shown microstructure of a sample from melt with a higher amount of iron. The structure consists of silicon eutectic, dendrites of $\alpha$ - phase excreted in the form of white units and black areas as iron based particles. The impact of the iron on iron based particles themselves is visible in the microstructure. The average length of these particles was approximately $37 \mu \mathrm{m}$.

To influence the segregation of iron based phases a master alloy $\mathrm{AlCr} 20$ was used. Different amounts of master alloy AlCr20 were added to the alloy with a higher amount of iron: $0.5 \%$ (melt No. 2), $1 \%$ (melt No. 3 ) and $1.5 \%$ (melt No. 4). The chemical compositions of these melts are in Table 3 .
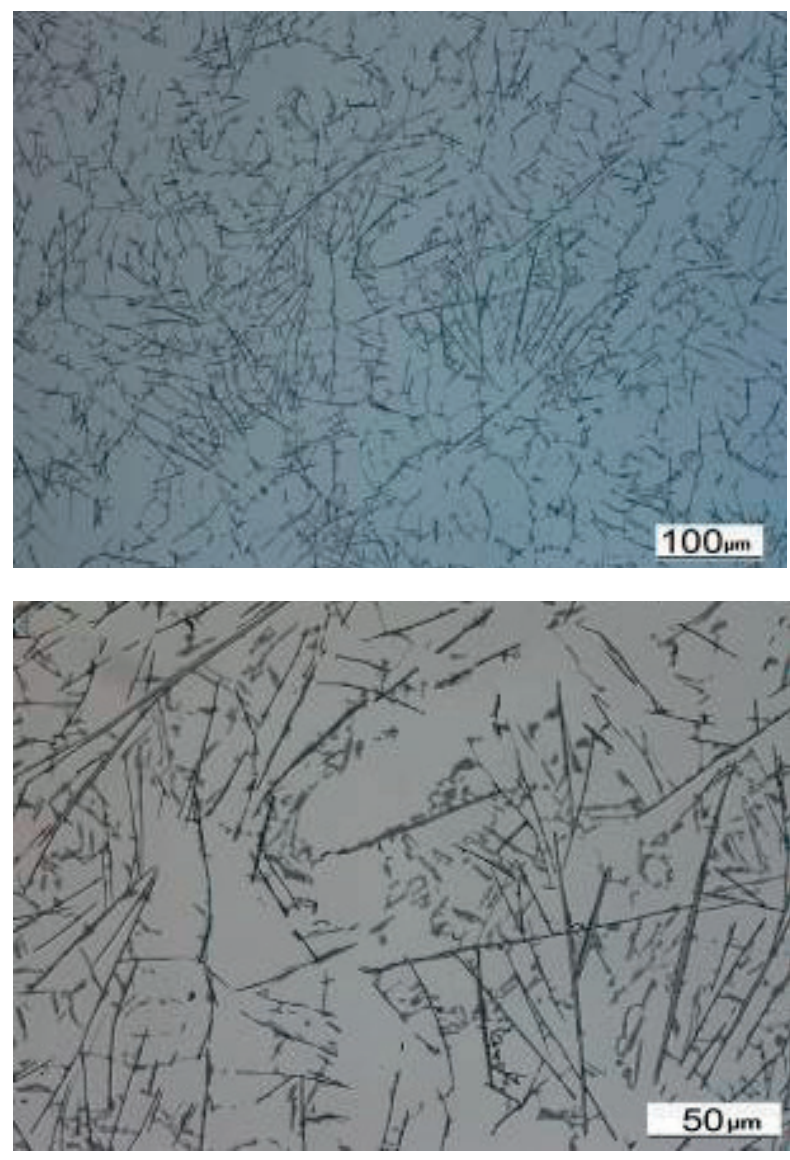

Mag. $200 \mathrm{x}$ and $500 x$, etching $20 \mathrm{ml} \mathrm{H} 2 \mathrm{SO}+100 \mathrm{ml} \mathrm{H} 2 \mathrm{O}$

Fig. 1 Microstructure of alloy with higher amount of iron

Chemical composition of melts after addition of master alloy $\mathrm{AlCr} 20$

Table 3 a) $0.5 \% \mathrm{Cr}$

\begin{tabular}{|c|c|c|c|c|c|c|c|c|c|c|c|}
\hline Elements & $\mathrm{Si}$ & $\mathrm{Fe}$ & $\mathrm{Cu}$ & $\mathrm{Mn}$ & $\mathrm{Mg}$ & $\mathrm{Ni}$ & $\mathrm{Cr}$ & $\mathrm{Pb}$ & $\mathrm{Ti}$ & $\mathrm{Zn}$ & $\mathrm{Sb}$ \\
\hline [wt. \%] & 6.41 & 1.737 & 0.054 & 0.128 & 0.330 & 0.080 & 0.289 & 0.006 & 0.111 & 0.027 & $<0.0004$ \\
\hline
\end{tabular}

b) $1 \% \mathrm{Cr}$

\begin{tabular}{|c|c|c|c|c|c|c|c|c|c|c|c|}
\hline Elements & $\mathrm{Si}$ & $\mathrm{Fe}$ & $\mathrm{Cu}$ & $\mathrm{Mn}$ & $\mathrm{Mg}$ & $\mathrm{Ni}$ & $\mathrm{Cr}$ & $\mathrm{Pb}$ & $\mathrm{Ti}$ & $\mathrm{Zn}$ & $\mathrm{Sb}$ \\
\hline [wt. \%] & 6.43 & 1.733 & 0.055 & 0.128 & 0.324 & 0.081 & 0.411 & 0.006 & 0.110 & 0.027 & $<0.0004$ \\
\hline
\end{tabular}


c) $1.5 \% \mathrm{Cr}$

\begin{tabular}{|c|c|c|c|c|c|c|c|c|c|c|c|}
\hline Elements & $\mathrm{Si}$ & $\mathrm{Fe}$ & $\mathrm{Cu}$ & $\mathrm{Mn}$ & $\mathrm{Mg}$ & $\mathrm{Ni}$ & $\mathrm{Cr}$ & $\mathrm{Pb}$ & $\mathrm{Ti}$ & $\mathrm{Zn}$ & $\mathrm{Sb}$ \\
\hline [wt. \%] & 6.45 & 1.654 & 0.055 & 0.119 & 0.347 & 0.081 & $\sim 0.472$ & 0.006 & 0.109 & 0.027 & $<0.0004$ \\
\hline
\end{tabular}

Taking a closer look at the chemical composition we can see an increasing amount of iron content with increasing amount of AlCr20 alloy. In all the cases there was an increase of iron content over $1 \% \mathrm{Fe}$ which is the maximum allowable content for this type of alloy. With the increasing amount of iron, the iron based particles also changed. In Figs. 2, 3 and 4 are shown microstructures of samples from melts with a higher amount of iron and with addition of $\mathrm{AlCr} 20$.
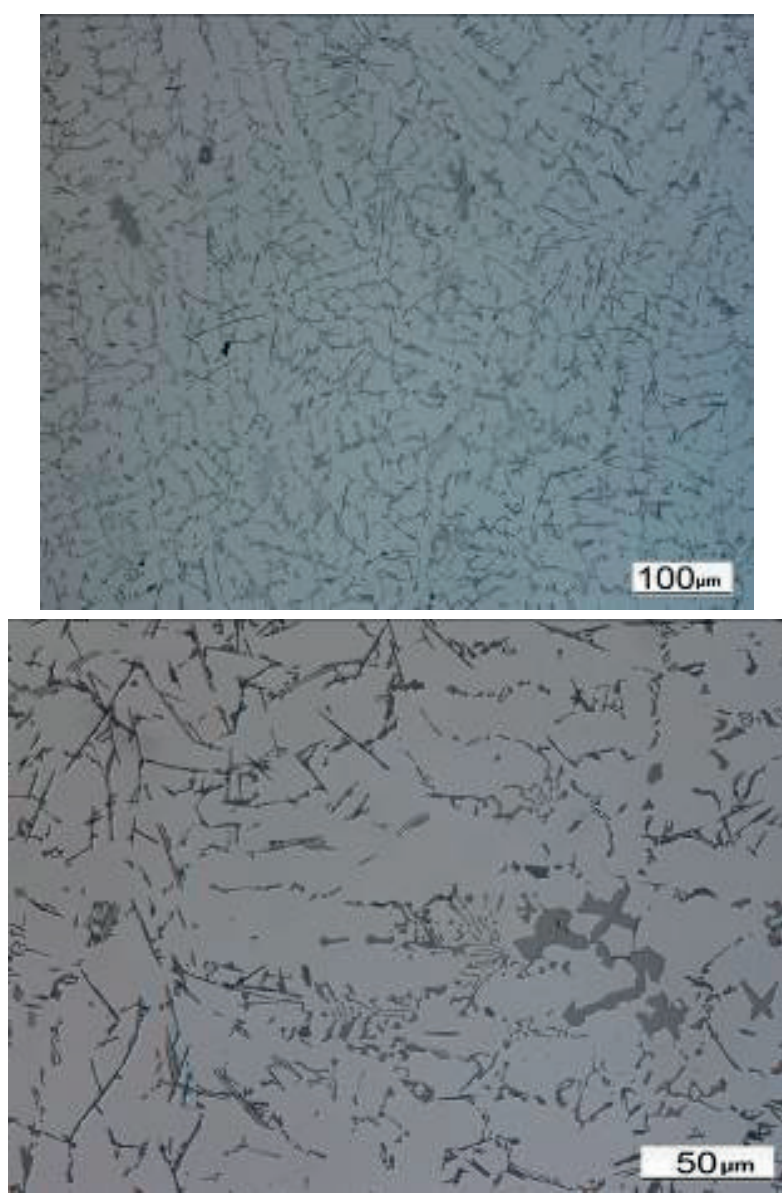

Mag. $200 \mathrm{x}$ and 500x, etching $20 \mathrm{ml} \mathrm{H2SO4}+100 \mathrm{ml} \mathrm{H} 2 \mathrm{O}$

Fig. 2 Microstructure of alloy with $0.5 \% \mathrm{Cr}$
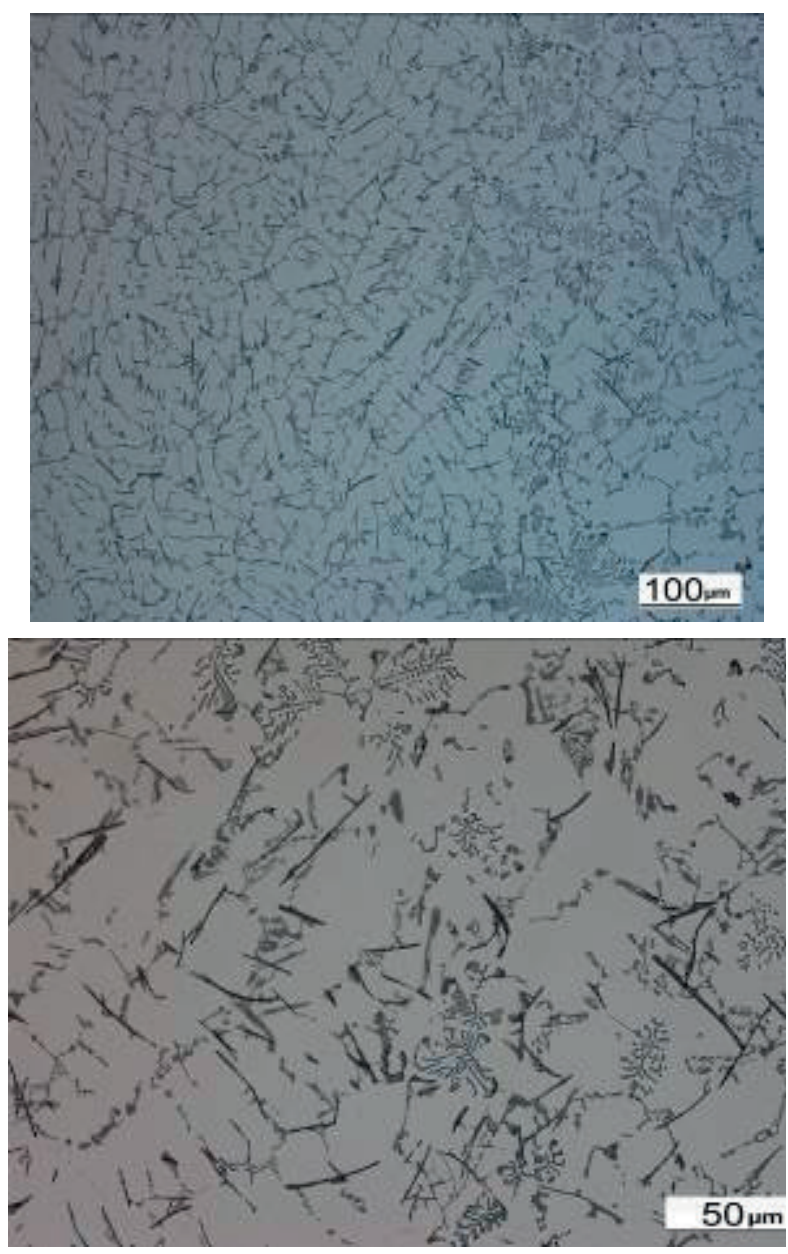

Mag. $200 \mathrm{x}$ and 500x, etching $20 \mathrm{ml} \mathrm{H} 2 \mathrm{SO}+100 \mathrm{ml} \mathrm{H} 2 \mathrm{O}$

Fig. 3 Microstructure of alloy with $1 \% \mathrm{Cr}$ 

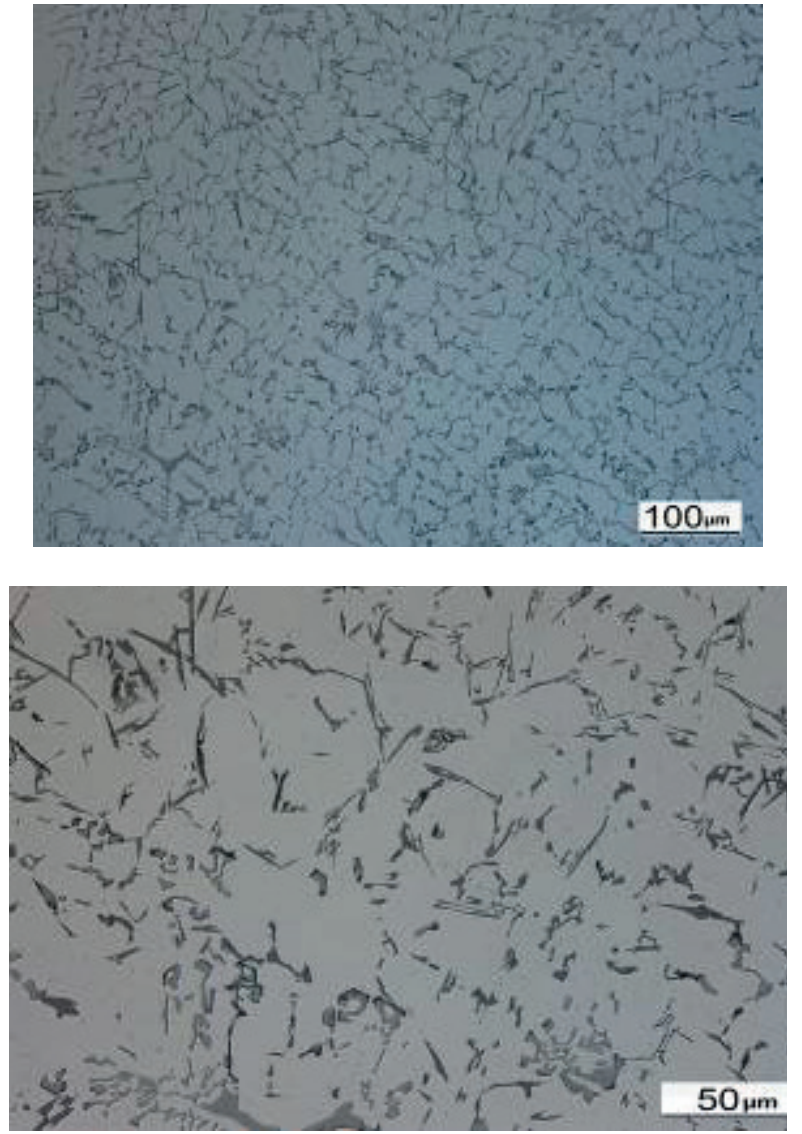

Mag. $200 \mathrm{x}$ and 500x, etching $20 \mathrm{ml} \mathrm{H} 2 \mathrm{SO} 4+100 \mathrm{ml} \mathrm{H} 2 \mathrm{O}$

Fig. 4 Microstructure of alloy with $1.5 \% \mathrm{Cr}$

In the mentioned figures we can see the change of iron based particles and their length. With increasing amount of $\mathrm{AlCr} 20$ master alloy, the length of iron based particles decreased. In case of $0.5 \% \mathrm{Cr}$, the length of iron based particles was approximately $19.6 \mu \mathrm{m}$, in case of $1 \% \mathrm{Cr}$ was approximately $11 \mu \mathrm{m}$ and in case of $1.5 \% \mathrm{Cr}$ was approximately $16.6 \mu \mathrm{m}$. It is also possible to see the presence of new particles which are not in shape of long thin needles.

Thermal analyses (Figs. 5, 6, 7 and 8) were recorded from all the melts. By evaluating the solidification curves it is impossible to see the exclusion of iron based phases, therefore, the first derivation of curves was made according to solidification time. In graphs we can be see the influence of different amounts of $\mathrm{Cr}$ in alloy and its influence on temperature of primary crystallization and also on temperature of eutectic reaction. In this area exclusion of iron based phases affected by chromium also occurs. To measure the solidification curves two thermocouples located in the sample mould were used; one at the wall and one at the centre. The use of the $\Delta \mathrm{T}$ curve allows identification of minor precipitation events that evolve only a small amount of latent heat and are, therefore, otherwise difficult to see on the derivate curve.

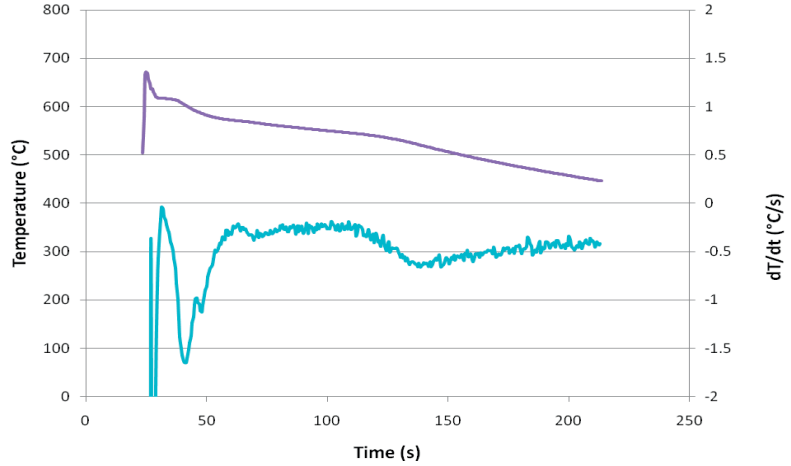

Fig. 5 Cooling curves graph of melting without addition of AlCr20

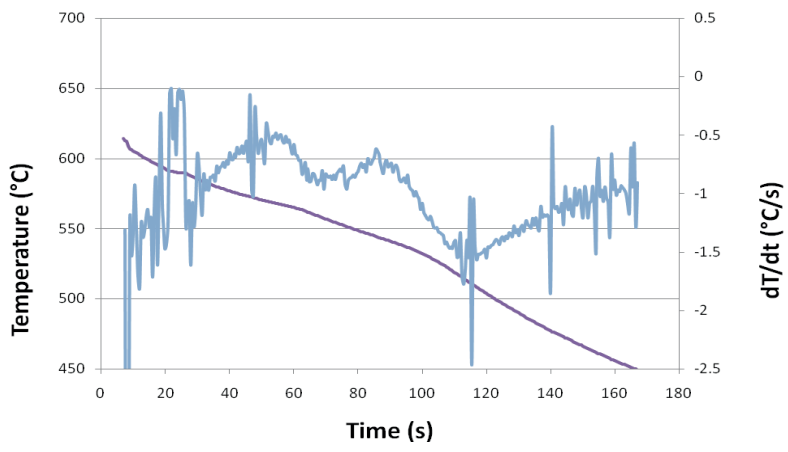

Fig. 6 Cooling curves graph of melting with 0.5 wt. \% of AlCr 20

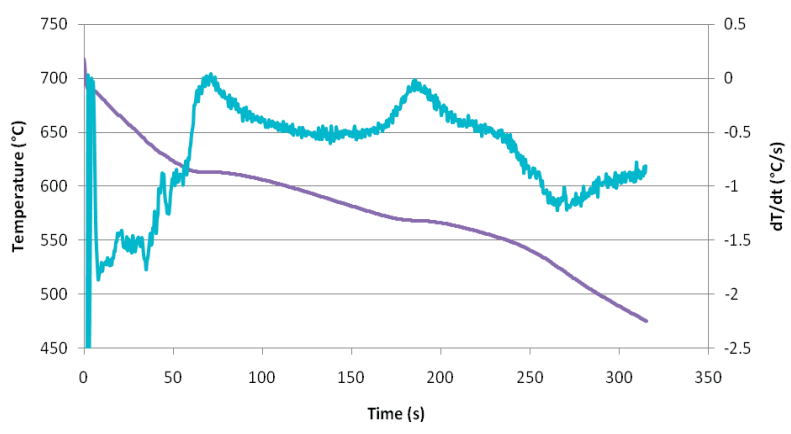

Fig. 7 Cooling curves graph of melting with 1 wt. \% of AlCr20

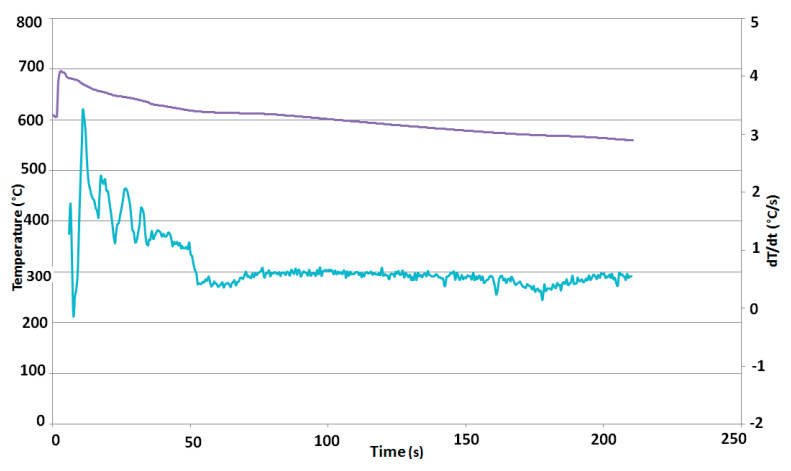

Fig. 8 Cooling curves graph of melting with 1.5 wt. \% of AlCr 20 
For all the samples tensile strength and elongation were evaluated. The tensile test was performed on a tensile machine WDW - 20 in the laboratory of mechanical tests, University of Zilina at $22{ }^{\circ} \mathrm{C}$. Results of tensile strength and elongation measurements are presented in Table 4.

Results of tensile strength and elongation before and after chrome addition

Table 4

\begin{tabular}{|c|c|c|}
\hline Alloy & Tensile strength [MPa] & Elongation [\%] \\
\hline AlSi7Mg0.3 & 170 & $1-2$ \\
\hline $0 \% \mathrm{Cr}$ & 167 & 0.93 \\
\hline $0.5 \% \mathrm{Cr}$ & 170 & 1.03 \\
\hline $1 \% \mathrm{Cr}$ & 173 & 1.26 \\
\hline $1.5 \% \mathrm{Cr}$ & 161 & 1.11 \\
\hline
\end{tabular}

\section{Conclusions}

The goal of the article was to evaluate the effect of chrome in secondary alloy $\mathrm{AlSi} 7 \mathrm{Mg} 0.3$. It is possible to conclude that high chrome content has detrimental influence on microstructure - occurrence of very thick and long iron based $\beta\left(\mathrm{Al}_{5} \mathrm{FeSi}\right)$. Presence of $\mathrm{AlCr} 20$ has also impact on the occurrence of other phases whose chemical composition will be examined by EDX analysis in further work. Addition of chrome increases tensile strength and decreases elongation; however, even higher amount of chrome decreases tensile strength. Therefore, we can say that chrome can be used as iron corrector in secondary aluminium alloys.

\section{Acknowledgment}

This work was created in the framework of the grant project VEGA c. 1/0363/13. The authors would like to thank the Grant Agency for support.

\section{References}

[1] KAHLIFA W.: Role Inclusions in the Precipitation of a-aluminium and Fe-intermetallics in Aluminium Rich Corner of the Al-Si-Fe Ternary System, 2003

[2] HURTAlOVA, L., TILlOVA, E.: Elimination of the Negative Effect of Fe-rich Intermetallic Phases in Secondary (recycled) Aluminium Cast Alloy. Manufacturing Technology, vol. 13, No. 1, 44-50, ISSN 1213-2489

[3] BRUNA, M., KUCHARCIK, L.: Prediction of the Porosity of Al Alloys. Manufacturing Technology, vol. 13, No. 3, 2013, 296-302, ISSN 1213-2489

[5] BOLIBRUCHOVA, D., RICHTARECH, L.: Effect of Adding Iron to the AlSi7Mg0.3 (EN AC 42 100, A356) Alloy. Manufacturing Technology, vol. 13, No. 3, 2013, 276-281, ISSN 1213-2489

[6] BOLIBRUCHOVA, D., RICHTARECH, L.: Study of the Gas Content in Aluminium Alloys. Manufacturing Technology, vol. 13, No.1, 2013, 276-281, ISSN 1213-2489

[7] BURSAK, M., BOKUVKA, O.: Influence of Technological Factors on Fatigue Properties of Steel Sheets. Communications Scientific Letters of the University of Zilina, vol. 8, No. 4, 34-37, ISSN 1335-4205

[8] PALCEK, P., HADZIMA, B., BOKUVKA, O., CHALUPOVA, M., NOVY, F.: Corrosion Resistance of Magnesium and its Alloys. Communications - Scientific Letters of the University of Zilina, vol. 5, No. 3, 2003, 21-22, ISSN 1335-4205

[9] TAYLOR, J. A.: The Effect of Iron in Al-Si Casting Alloys. 35 th Australian Foundry Institute National Conference, Adelaide, 2004, 148-157

[10] TILlova, E., CHALUPOVA, M., HURTAlOVA, L., DURNIKOVA, E.: Quality Control of Microstructure in Recycled Al-Si Cast Alloys. Manufacturing Technology, vol. 11, No. 11, 70-76. 